\title{
ANALYSIS OF LIFE-COURSE FACTORS INFLUENCING GROWTH AND DEVELOPMENT IN CHILDREN UNDER 3 YEARS OLD OF EARLY MARRIAGE WOMEN IN KEDIRI
}

\author{
Umianita Risca Wulandari ${ }^{1}$, Uki Retno Budihastuti ${ }^{2}$, \\ Eti Poncorini Pamungkasari3) \\ 1)Masters Program in Public Heath, Sebelas Maret University \\ 2)Department of Obstetrics and Gynecology, Dr. Moewardi Hospital, Surakarta \\ 3) Faculty of Medicine, Sebelas Maret University
}

\begin{abstract}
Background: Children is the future pillar of our nation. As such, children need is important to be fulfilled. Physical, mental, and emotional conditions of mothers during gestation period play an important role in growth and development of children. This study aimed to determine life-course factors influencing growth and development in children under 3 years old of early marriage women.
\end{abstract}

Subjects and Method: This was an analytic observational study with retrospective cohort design. This study was conducted at Sukorame and Campurejo Health Center, Kediri, East Java, on March, 2017. A sample of 120 children under 3 years old were selected for this study by fixed exposure sampling. The dependent variable was child growth (weight for age) and development. The independent variables were marital age, maternal mid upper arm circumference (MUAC) during pregnancy, gestational age of birth delivery, family stimulation, maternal education, and family income. The data of child weight were measured by scales and recorded in maternal and child health book. The data of other variables were measured by a set of questionnaire. The data were analyzed by path analysis.

Results: Child growth (weight for age) was affected by birthweight $(b=0.07$; $\mathrm{SE}=0.02 ; \mathrm{p}<0.001)$ and family income $(\mathrm{b}=0.04 ; \mathrm{SE}=0.02 ; \mathrm{p}=0.070)$. Birthweight was affected by maternal education $(\mathrm{b}=2.11 ; \mathrm{SE}=1.83 ; \mathrm{p}=$ 0.248), gestational age of birth $(b=0.67 ; \mathrm{SE}=0.22 ; \mathrm{p}=0.002)$, maternal MUAC $(b=1.46 ; S E=0.24 ; p=0.002)$, and family income $(b=0.22 ; S E=0.09$, $\mathrm{p}=0.012)$. Family income was affected by marital age $(b=0.68 ; \mathrm{SE}=0.07$; $\mathrm{p}<0.001)$. Maternal MUAC during pregnancy was affected by marital age $(\mathrm{b}=$ $0.12 ; \mathrm{SE}=0.03 ; \mathrm{p}<0.001)$. Maternal education was affected by marital age $(b=0.01 ; \mathrm{SE}<0.01 ; \mathrm{p}=0.002)$. Family stimulation was affected by family income $(b=0.75 ; \mathrm{SE}=0.26 ; \mathrm{p}=0.003)$. Child development was affected by marital age $(b=0.07 ; \mathrm{SE}=0.02 ; \mathrm{p}=0.001)$, family stimulation $(\mathrm{b}=0.02 ; \mathrm{SE}=$ $0.01 ; \mathrm{p}<0.001)$, and birthweight $(\mathrm{b}<0.01 ; \mathrm{SE}<0.01 ; \mathrm{p}=0.373)$.

Conclusion: Child growth of under 3 years old (weight for age) is directly affected by birthweight and family income, and indirectly affected by some other factors. Child development is directly affected by marital age, family stimulation, and birthweight, and indirectly affected by some other factors.

Keywords: life-course, growth, development, children under 3 years old

Correspondence: Umianita Risca Wulandari. Masters Program in Public Health, Sebelas Maret University, Jl. Ir. Sutami 36 A, Surakarta 57126, Central Java, Indonesia. Email: umianitao3@gmail.com.

Mobile: +6285736404487 . 